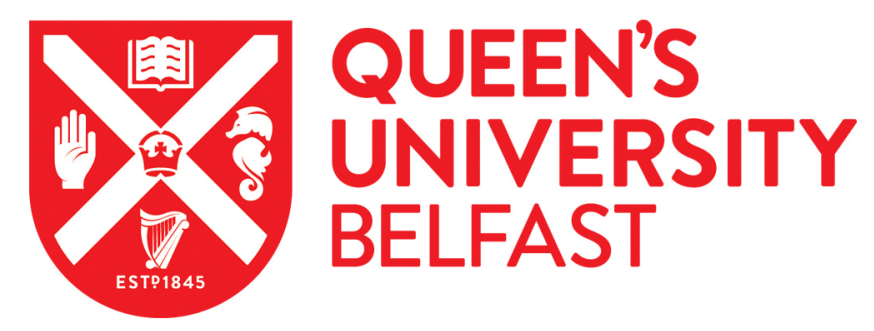

\title{
Pharmacogenetics of platinum-based chemotherapy: impact of DNA repair and folate metabolism gene polymorphisms on prognosis of
} non-small cell lung cancer patients

Perez Ramirez, C., Canadas Garre, M. L., Alnatsha, A., Villar, E., Valdivia-Bautista, J., Faus Dader, M. J., \& Calleja Hernandez, M. A. (2018). Pharmacogenetics of platinum-based chemotherapy: impact of DNA repair and folate metabolism gene polymorphisms on prognosis of non-small cell lung cancer patients. The pharmacogenomics journal. https://www.nature.com/articles/s41397-018-0014-8

Published in:

The pharmacogenomics journal

Document Version:

Peer reviewed version

Queen's University Belfast - Research Portal:

Link to publication record in Queen's University Belfast Research Portal

\section{Publisher rights}

Copyright 2017 Nature. This work is made available online in accordance with the publisher's policies. Please refer to any applicable terms of use of the publisher.

\section{General rights}

Copyright for the publications made accessible via the Queen's University Belfast Research Portal is retained by the author(s) and / or other copyright owners and it is a condition of accessing these publications that users recognise and abide by the legal requirements associated with these rights.

Take down policy

The Research Portal is Queen's institutional repository that provides access to Queen's research output. Every effort has been made to ensure that content in the Research Portal does not infringe any person's rights, or applicable UK laws. If you discover content in the Research Portal that you believe breaches copyright or violates any law, please contact openaccess@qub.ac.uk. 
INDEX

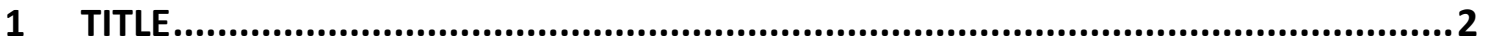

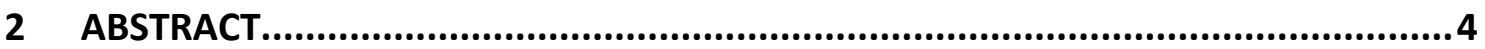

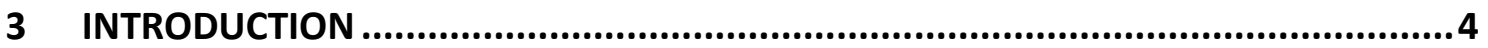

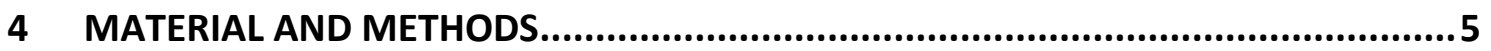

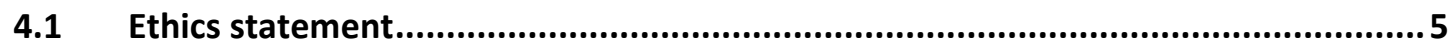

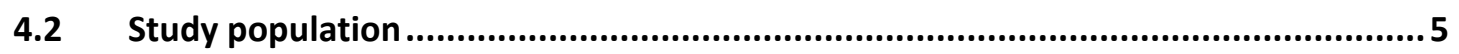

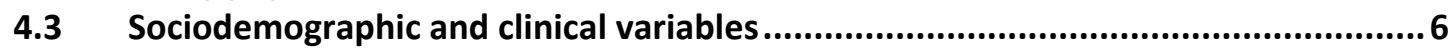

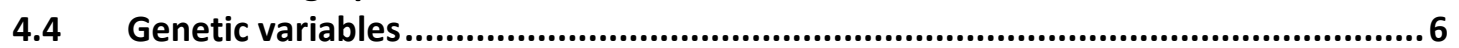

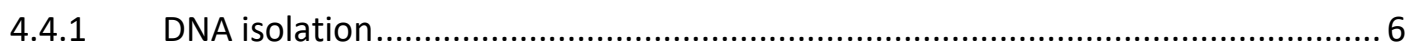

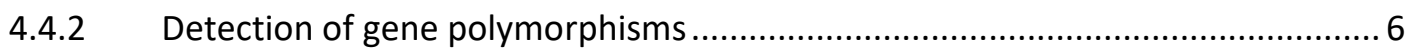

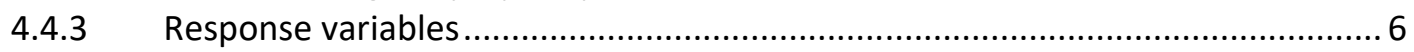

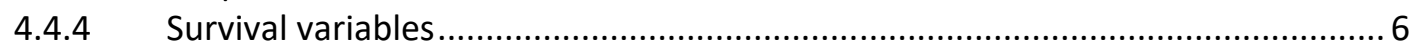

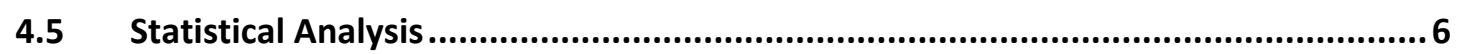

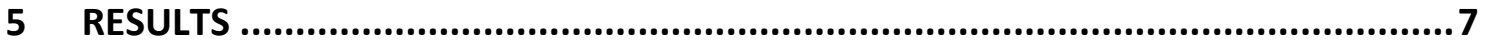

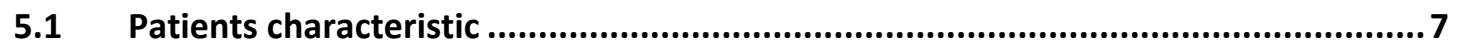

5.2 Influence of clinico-pathologic characteristics on clinical outcomes of platinum-

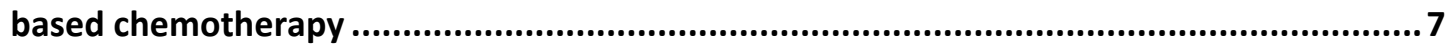

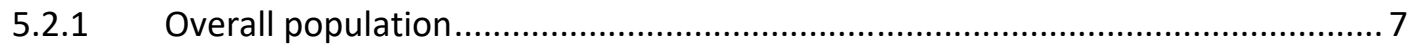

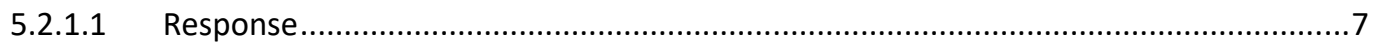

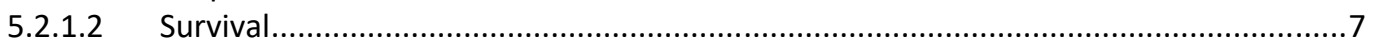

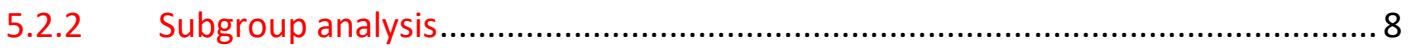

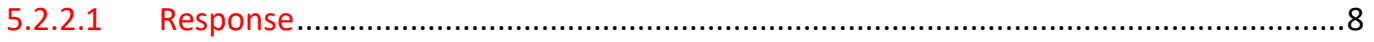

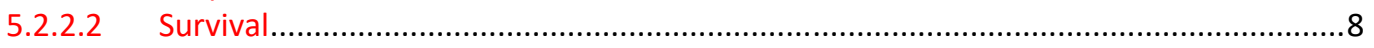

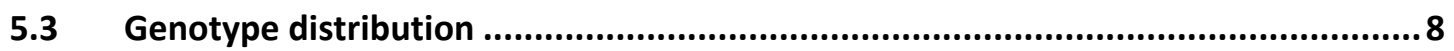

5.4 Influence of gene polymorphisms on clinical outcomes of platinum-based chemotherapy.

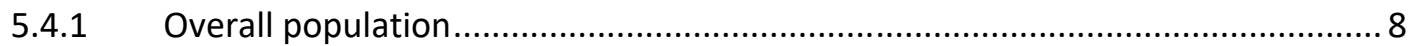

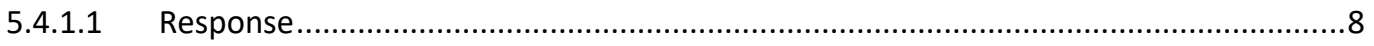

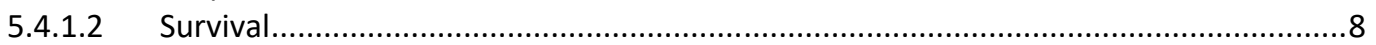

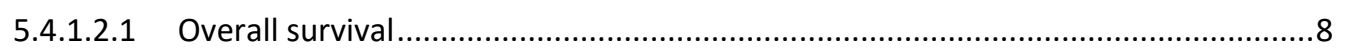

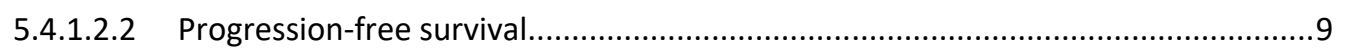

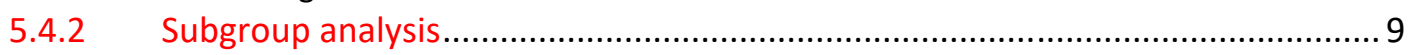

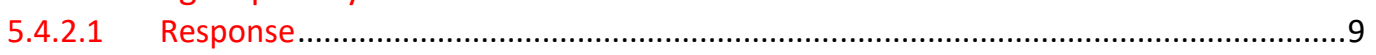

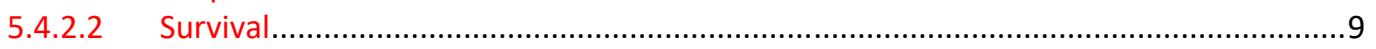

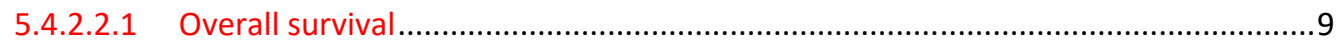

5.4.2.2.2 Progression-free survival................................................................. 10

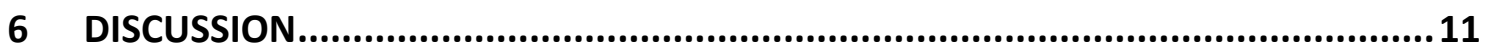

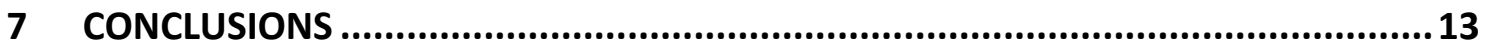

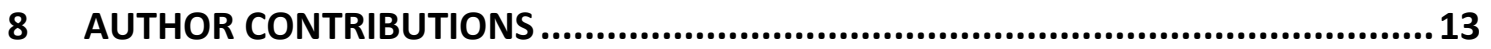

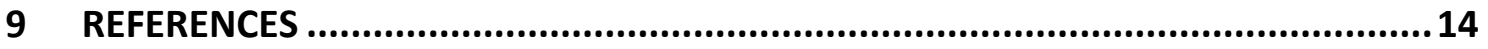

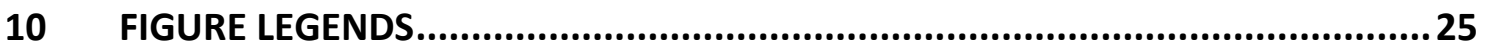




\section{TITLE}

PHARMACOGENETICS OF PLATINUM BASED CHEMOTHERAPY: IMPACT OF DNA REPAIR AND FOLATE METABOLISM GENE POLYMORPHISMS ON PROGNOSIS OF NON-SMALL CELL LUNG CANCER PATIENTS

\section{AUTHORS:}

Cristina Pérez-Ramírez ${ }^{1,2}$, Marisa Cañadas-Garre ${ }^{1,3}$, Ahmed Alnatsha ${ }^{3}$, Eduardo Villar ${ }^{4}$, Javier Valdivia-Bautista ${ }^{5}$, María José Faus-Dáder ${ }^{2}$, Miguel Ángel Calleja-Hernández ${ }^{1,6}$.

\section{Author for correspondence}

$2 \quad$ Marisa Cañadas-Garre.

Pharmacogenetics Unit

UGC Provincial de Farmacia de Granada

Instituto de Investigación Biosanitaria de Granada

Complejo Hospitalario Universitario de Granada

Avda. Fuerzas Armadas, 2

18014 Granada, Spain

Telephone: $\quad+34958020108$

Fax: $\quad+34901021804$

Affiliations

E-mail: marisacgarre@gmail.com

\section{Pharmacogenetics Unit}

UGC Provincial de Farmacia de Granada

Instituto de Investigación Biosanitaria de Granada

Complejo Hospitalario Universitario de Granada

Avda. Fuerzas Armadas, 2

Telephone: $\quad+34958020108$

Fax: $\quad+34901021804$

2 Department of Biochemistry

Faculty of Pharmacy

University of Granada

Campus Universitario de Cartuja, s/n

18071 Granada, Spain

Telephone: +34958243838

3 Queen's University Belfast

Centre for Public Health

Nephrology Research Group

c/o Regional Genetics Centre, Level A, Tower Block

Belfast City Hospital, Lisburn Road

Belfast, BT9 7AB

Telephone: +4402890638460

Fax: +4402890 235900

4 Department of Molecular Medicine

Faculty of Medicine

University of Tübingen

Geissweg 5

72076 Tübingen

Telephone: $\quad$ +4907071 29-73682

5 Pathology Service

UGC Anatomía Patológica

Instituto de Investigación Biosanitaria de Granada

Complejo Hospitalario Universitario de Granada 
Avda. Fuerzas Armadas, 2

18014 Granada, Spain

Telephone: +34958020374

6

Medical Oncology Service

UGC Oncología Médica

Instituto de Investigación Biosanitaria de Granada

Complejo Hospitalario Universitario de Granada

Avda. Fuerzas Armadas, 2

18014 Granada, Spain

Telephone: +34958020346

7 Department of Pharmacology

Faculty of Pharmacy

University of Granada

Campus Universitario de Cartuja, $\mathrm{s} / \mathrm{n}$

18071 Granada, Spain

Telephone: +34958243538

Mails

Cristina Pérez-Ramírez

cperezramirez87@gmail.com

Marisa Cañadas-Garre

marisacgarre@gmail.com

Ahmed Alnatsha

Eduardo Villar

Javier Valdivia Bautista

María José Faus-Dáder

r.j.b-man@hotmail.com

eduardovillar6@gmail.com

javaldi@yahoo.com

Miguel Ángel Calleja Hernández

mfaus@ugr.es

mangel.calleja.sspa@juntadeandalucia.es

Keywords:

PLATINUM BASED CHEMOTHERAPY

NON-SMALL CELL LUNG CANCER

RESPONSE

SURVIVAL

POLYMORPHISMS

WORD COUNT (excluding references and figure legends):

Abstract: $\quad 223$ words

Main Text: 3061 words

\section{FUNDING}

This work was partly supported by a research grant for Cristina Pérez-Ramírez (FPU12/04722), from Ministerio de Educación, Cultura y Deporte.

\section{CONFLICT OF INTEREST}

The authors declare that there is not conflict of interest that could be perceived as prejudicing the impartiality of the research reported and there is not any competing financial interest in relation to the work described in this article.

\section{ACKNOWLEDGMENTS}

The results of this investigation are part of the doctoral thesis presented by Cristina PérezRamírez at the University of Granada. 


\section{ABSTRACT}

Chemotherapy based on platinum compounds is the standard treatment for NSCLC patients with EGFR wild-type, and is also used as second line in mutated EGFR patients. Nevertheless, this therapy presents poor clinical outcomes. ERCC1, ERCC2, XRCC1, MDM2, MTHFR, MTR and $S L C 19 A 1$ gene polymorphisms may contribute to individual variation in response and survival to platinum-based chemotherapy. The aim of this study was to investigate the influence of these polymorphisms on response and survival of NSCLC patients treated with platinum-based chemotherapy. A retrospective-prospective cohorts study was conducted, including 141 NSCLC patients. Polymorphisms were analyzed by PCR Real-Time with Taqman ${ }^{\circledR}$ probes. Patients with ERCC1 rs3212986-GG ( $\left.\mathrm{p}=0.0268 ; \mathrm{OR}=2.50 ; \mathrm{Cl}_{95 \%}=1.12-5.69\right)$ and XRCC1 rs25487-GG ( $\mathrm{p}=0.0161$; $\left.\mathrm{OR}=2.99 ; \mathrm{Cl}_{95 \%}=1.26-7.62\right)$ genotype showed significantly better ORR. Cox survival analysis revealed that patients carrying the MDM2 rs1690924-GG genotype $(p=0.0345$; HR $=1.99$; $\left.\mathrm{Cl}_{95 \%}=1.05-3.80\right)$ presented higher risk of death. Furthermore, carriers of MTR rs 1805087-A alleles $\left(p=0.0060 ; \mathrm{HR}=8.91 ; \mathrm{Cl}_{95 \%}=1.87-42.42\right)$ and SLC19A1 rs1051266-AA genotype $(\mathrm{p}=0.0130$; $\mathrm{HR}=1.74 ; \mathrm{Cl}_{95 \%}=1.12-2.68$ ) showed greater risk of progression. No influence of $E R C C 1 \mathrm{rs} 11615$, ERCC2 rs13181, ERCC2 rs1799793, XRCC1 rs1799782, MDM2 rs1470383, MTHFR rs1801131 and MTHFR rs1801133 on platinum-based chemotherapy clinical outcomes was found. In conclusion, our results suggest that ERCC1 rs3212986, XRCC1 rs25487, MDM2 rs1690924, MTR rs1805087 and SLC19A1 rs1051266 gene polymorphisms may significantly act as predictive factors in NSCLC patients treated with platinum-based chemotherapy.

\section{INTRODUCTION}

Lung cancer is the highest mortal cancer among both genders, being responsible for $27 \%$ of all cancer deaths ${ }^{1}$. This type of tumor is the second most diagnosed (after prostate in men and breast cancer in woman), showing $14 \%$ of incidence ${ }^{1}$. In accordance with the latest cancer statistics, around 224,300 new cases and 158,000 deaths are expected to occur in the United States in $2016^{1}$.

Non-small cell lung cancer (NSCLC) is the lung cancer subtype diagnosed in up to $85 \%$ of all cases. NSCLC and is classified in three subtypes: squamous cell carcinoma, adenocarcinoma and large cell carcinoma. In accordance with the American Joint Committee on Cancer (AJCC), the majority of the patients are catalogued as advanced stage (IIIB-IV) at the time of diagnosis 2-4.

Chemotherapy based on platinum compounds is the standard treatment for NSCLC patients with EGFR wild-type, and is also used as second line in mutated EGFR patients ${ }^{5}$. This therapy is usually given combined with third-generation drug such as, anti-microtubule agents (taxanes and vinca alkaloids), antifolate agents (pemetrexed), or pyrimidine antagonists (gemcitabine). Chemotherapy versus best supportive care has showed improvement in terms of survival (10.7 months vs 3.9 months, respectively; $\mathrm{p}<0.001$ ) and symptom control compared with best supportive care ${ }^{6,7}$. Nevertheless, the overall response rate (ORR) to platinum-based regimen is about $13-47.2 \%$ and only $16 \%$ of the patients are alive five years after diagnosis ${ }^{8-24}$. The knowledge of predictive and/or prognostic factors may improve clinical outcomes of NSCLC therapy, by stratifying patients into subgroups that could be managed differently. The crucial factor for NSCLC prognosis is the cancer stage, but a significantly variability in terms of response and survival has been described among patients with the same stage of disease, suggesting that other factors may play a role on NSCLC prognosis ${ }^{4,25}$. Interestingly, genetic factors such as single nucleotide polymorphisms (SNPs) have demonstrated to be associated with inter-individual differences in response and survival in NSCLC patients ${ }^{26-42}$.

The main platinum drugs compounds used in NSCLC therapy are cisplatin and carboplatin. They share the same mechanism of action, interfering with DNA and forming DNA adducts, 
which induce severe local distortions of the DNA double helix ${ }^{43},{ }^{44}$. In response to this DNA damage, various signaling pathways are activated, such as DNA repair and p53 pathways ${ }^{45-47}$. The DNA repair pathways are responsible for detecting and repairing these damaged DNA. Nucleotide-excision repair (NER) and base excision repair (BER) are the two most important DNA repair pathways and are comprised by several proteins, such as excision repair crosscomplementing group 1 (ERCC1), excision repair cross-complementation group 2 (ERCC2, also known as XPD) and X-ray repair complementing defective repair in Chinese hamster cells 1 (XRCC1) ${ }^{45,}{ }^{46}$. The p53 pathway is involved in modulating cell cycle and apoptosis ${ }^{47}$. The principal antagonist of TP53 tumor suppressor gene is MDM2 proto-oncogene, E3 ubiquitin protein ligase (MDM2), that induces its ubiquitination and degradation ${ }^{48}$. Genetic variants in these genes have showed to be associated with variability in clinical outcomes for NSCLC patients treated with platinum-based chemotherapy ${ }^{26-33}$.

Other pathways have also demonstrated to be connected with effectiveness of platinum compounds, such as folate metabolism ${ }^{34-41}$. Folate metabolism is involved in DNA methylation through methylenetetrahydrofolate reductase (MTHFR) and methionine synthase (MTR) enzymes. Genetic alterations in these genes disturb methylation of DNA and tumor-suppressor genes, which may influence the clinical outcomes of platinum-based chemotherapy ${ }^{34-36,39}$. Other gene with a crucial function on folate metabolism is solute carrier family 19 (folate transporter), members 1 (SLC19A1). This transporter is involved in the intracellular uptake of pemetrexed, a drug that is usually given in combination with platinum compounds ${ }^{39,} 49$. Genetic variants in this gene may modify pemetrexed transport and consequently affect the effectiveness of pemetrexed-based chemotherapy ${ }^{37-41}$.

In this study, we investigated the association between clinical outcomes of platinum-based chemotherapy and genetic alterations in ERCC1, ERCC2, XRCC1, MDM2, MTHFR, MTR and SLC19A1 genes in NSCLC patients. To determine the impact of the tumor biology, we also performed a subgroup analysis according to EGFR status.

\section{MATERIAL AND METHODS}

A retrospective-prospective cohorts study was conducted.

\subsection{Ethics statement}

This study was approved by the Complejo Hospitalario Universitario de Granada (CHUG) Ethics and Research Committee and was performed in accordance with the declaration of Helsinki. Patients signed a written informed consent form for blood or saliva sample collection and genotyping analysis. Sample identification was based on non-patient codes.

\subsection{Study population}

One hundred and forty-one patients diagnosed with NSCLC between 2003-2015, at the CHUG, Granada, Spain were enrolled in the study and followed up until February 2016. Patients who were age $\geq 18$ years, histologically or cytologically diagnosed NSCLC (stages I-IV), confirmed adequate bone marrow reserve (hemoglobin $\geq 9 \mathrm{~g} / \mathrm{dl}$, neutrophil count $\geq 1500 \mathrm{cells} / \mathrm{mm}^{3}$, and platelet count $\geq 100.000$ cells $/ \mathrm{mm}^{3}$ ), adequate liver (bilirubin $\leq 1.5 \mathrm{mg} / \mathrm{dl}$, aspartate aminotransferase and alanine aminotransferase $\leq 2.5$ times the upper limit of normal) and renal function (creatinine level $\leq 1.5 \mathrm{mg} / \mathrm{dL}$ ) and measurable disease by computed tomography of the thorax and abdomen were suitable for the study.

The 141 NSCLC patients were treated with cisplatin or carboplatin intravenously in combination with a third-generation drug (gemcitabine, paclitaxel, pemetrexed and vinorelbine) according to the National Comprehensive Cancer Network version 4.2016 guidelines ${ }^{5}$. Hematology and biochemistry analyses were done at the end of each cycle.

The status of epidermal growth factor (EGFR) was analyzed by cobas ${ }^{\circledR}$ EGFR Mutation Test ${ }^{50}$. 


\subsection{Sociodemographic and clinical variables}

Sociodemographic data including gender, family history of cancer, previous non-lung cancer, previous lung disease, smoking status and age at diagnosis was collected from clinical records. Clinical data were also collected from clinical records and comprised tumor histology and stage, chemotherapy agents, surgery, radiotherapy and EGFR status. The tumor staging was performed based on AJCC cancer staging manual ${ }^{51}$.

\subsection{Genetic variables}

\subsubsection{DNA isolation}

Blood samples $\left(3 \mathrm{ml}\right.$ ) were collected in BD Vacutainer ${ }^{\circledR}$ K3E Plus Blood Collection Tubes. Saliva samples were collected in $50 \mathrm{ml} \mathrm{BD} \mathrm{Falcon}{ }^{\mathrm{TM}}$ conical tubes (BD, Plymouth, UK). DNA isolation was performed using the QIAamp DNA Mini Kit (QiagenGmBH, Hilden, Germany) according to the manufacturer's instructions for DNA purification from blood or saliva and stored at $-40{ }^{\circ} \mathrm{C}$.

\subsubsection{Detection of gene polymorphisms}

ERCC1 C118T (rs11615), ERCC1 C8092A (rs3212986), ERCC2 Lys751GIn (rs13181), ERCC2 Asp312Asn (rs1799793), XRCC1 Arg194Trp (rs1799782), XRCC1 Gln399Arg (rs25487), MDM2 (rs1470383), MDM2 (rs1690924), MTHFR A1298C (rs1801131), MTHFR C677T (rs1801133), MTR (rs1805087) and SLC19A1 Arg27His (rs1051266) gene polymorphisms were analyzed by Real-Time PCR using TaqMan ${ }^{\circledR}$ probes. Genotyping methodology was previously described ${ }^{52}$.

\subsubsection{Response variables}

Platinum-based chemotherapy response was evaluated based on the Response Evaluation Criteria in Solid Tumors (RECIST) guideline (Version 1.1) ${ }^{53}$.

Patients classified as Complete Response (CR) + Partial Response (PR) were catalogued as responders to treatment and Stable Disease (SD) + Progressive disease (PD) as nonresponders.

\subsubsection{Survival variables}

Survival was evaluated through OS and PFS, which were measured as follows:

OS as time from cancer diagnosis until final follow-up or death

PFS as the time from initiation of treatment to relapse, death or last known follow-up.

Mortality related data were collected from clinical records and the population-based Cancer Registry of Granada.

\subsection{Statistical Analysis}

Deviation from Hardy Weinberg equilibrium and pairwise linkage disequilibrium for each polymorphism were calculated using the free, open-source whole genome association analysis toolset PLINK ${ }^{54}$.

Quantitative data were estimated as the mean ( \pm standard deviation) for normally-distributed variables or medians and percentiles (25 and 75$)$ for non-normal distributed variables. The Shapiro-Wilks test was used to assess normality.

The bivariate association between response with demographic, clinical and genetic variables was tested using the Pearson's chi-square or Fisher's exact test, and evaluated by relative risk (RR) and their corresponding 95\% confidence intervals (Cl).

The Kaplan-Meier method and the log-rank test were employed to assess associations between survival with demographic, clinical and genetic variables. 
All clinical and genetic variables associated with outcomes in bivariate analysis were tested as potential confounding factors in multivariate analysis. Multivariate Cox proportional hazard regression model (backward stepwise method) was used to estimate the adjusted hazards ratio (HR) and $95 \%$ confidence interval $\left(\mathrm{Cl}_{95 \%}\right)$ for potential predictive factors for survival. The influence of SNPs and clinical variables on response was analyzed using a multivariate logistic regression model (backward stepwise method).

All tests were two-sided and a probability of 0.05 or smaller was considered statistically significant. Data analysis was performed using R 3.0.1 ${ }^{55}$.

\section{RESULTS}

\subsection{Patients characteristic}

A total of 141 patients with cytologically or histologically confirmed NSCLC were recruited in the study. The baseline characteristics are listed in Table 1 . The median age was $61[52,67]$ years, and 104 were males (104/141; 73.76\%); 70.5\% presented advanced stage (IIIB-IV) (98/139). All patients were treated with platinum-based chemotherapy in addition to one third-generation chemotherapy drug, such as gemcitabine $(21 / 141 ; 14.89 \%)$, paclitaxel $(33 / 141 ; 23.40 \%)$, pemetrexed $(37 / 141 ; 26.24 \%)$ or vinorelbine $(50 / 141 ; 35.46 \%)$.

Response to treatment ( $C R+P R$ ) was shown in 98 patients (98/141; 70.5\%). Regarding treatment options, response to chemotherapy was higher in those patients who received adjuvant chemotherapy $(93.8 \% ; 15 / 16)$, whereas as response to chemotherapy given as palliative treatment was $50.8 \%$ (31/61) (Table 1). During follow-up, 75 death events were documented. Median OS and PFS were $32.2[27.0,52.2]$ and $14.3[10.2,18.4]$ months for all patients, respectively. However, for patients with advanced stage survival was 25.8 [21.1, 32.2] for OS and $10.2[8.37,5.0]$ for PFS.

\subsection{Influence of clinico-pathologic characteristics on clinical outcomes of platinum-based chemotherapy}

\subsubsection{Overall population}

\subsubsection{Response}

Response was better in squamous cell carcinoma $\left(p=0.0342 ; R R=1.30 ; C_{95 \%}=1.02-1.66\right.$; Table S1), I, II and IIIA stage ( $p=0.0053 ; R R=1.41 ; C_{95 \%}=1.11-1.79$; Table S1), and tumor resection $\left(p=0.0004 ; R R=1.56 ; C_{95 \%}=1.22-1.99 ;\right.$ Table S1).

\subsubsection{Survival}

The clinical factors associated with OS were: female ( $p_{\text {log-rank }}=0.0082 ; 85.4$ vs 27.0 months; Table S2; Figure S1), squamous cell carcinoma ( $p_{\text {log-rank }}=0.0021 ; 59.4$ vs 26.1 months; Table S2; Figure S2), I, II and IIIA stage ( $p_{\text {log-rank }}<0.001 ; 85.4$ vs 25.8 months; Table S2; Figure S3), paclitaxel chemotherapy agent ( $p_{\text {log-rank }}<0.001$; Table S2; Figure $\left.S 4\right)$ and tumor resection ( $p_{\text {log- }}$ rank $<0.001 ; 114.0$ vs 26.1 months; Table S2; Figure S5). Similarly, median PFS was better in female $\left(p_{\text {log-rank }}=0.0418 ; 19.6\right.$ vs 11.0 months; Table S3; Figure S6), squamous cell carcinoma ( log-rank $_{1}=0.0034 ; 27.3$ vs 11.4 months; Table S3; Figure S7), I, II and IIIA stage ( $p_{\text {log-rank }}<0.001$; 44.0 vs 10.2 months; Table S3; Figure S8), paclitaxel as chemotherapy agent ( $p_{\text {log-rank }}<0.001$; Table S3; Figure S9), tumor resection ( $p_{\text {log-rank }}<0.001 ; 197.0$ vs 17.0 months; Table S3; Figure S10). A trend towards better PFS was showed in those patients who received concomitant or concurrent radiotherapy but it was not statistically significant ( $p_{\log \text {-rank }}=0.0566 ; 23.2$ vs 11.2 months; Table S3; Figure S11). 


\subsubsection{Subgroup analysis}

\subsubsection{Response}

In the subgroup of native EGFR response was better in I, II and IIIA stage ( $p=0.0291 ; R R=1.63$; $\mathrm{Cl}_{95 \%}=1.05-2.53$; Table S4), and tumor resection ( $\mathrm{p}=0.0057 ; \mathrm{RR}=1.74 ; \mathrm{Cl}_{95 \%}=1.12-2.70 ;$ Table S4). However, in patients with mutations in EGFR no association with clinical or demographic characteristics was found (Table S5).

\subsubsection{Survival}

For patients with native EGFR median OS was higher in females ( plog-rank $=0.0336 ; 47.4$ vs 24.5 months; Table S6; Figure S12), personal history of cancer ( $p_{\text {log-rank }}=0.0319 ; 47.4$ vs 25.4 months; Table S6; Figre S13), I, II and IIIA stage (plog-rank $=0.0113$; 59.4 vs 23.1 months; Table S6; Figure S14), paclitaxel chemotherapy agent ( $p_{\text {log-rank }}<0.001$; Table S6; Figure S15) and surgery as first course of treatment ( $p_{\text {log-rank }}=0.0018 ; 73.9$ vs 23.1 months; Table S6; Figure S16). Similarly, median PFS was higher in females ( $p_{\text {log-rank }}=0.017 ; 18.7$ vs 8.5 months; Table S7; Figure S17), I, II and IIIA stage ( $p_{\text {log-rank }}=0.014 ; 23.3$ vs 10.0 months; Table S7; Figure S18), paclitaxel chemotherapy agent ( $p_{\text {log-rank }}<0.001$; Table S7; Figure S19) and surgery as first course of treatment ( $p_{\text {log-rank }}<0.001 ; 40.8$ vs 9.2 months; Table S7; Figure S20).

In the subgroup of patients with mutations in EGFR median OS was higher in females ( $p_{\text {log- }}$ $r_{r a n k}=0.005 ; 52.2$ vs 21.1 months; Table S8; Figure S21) and tumor resection ( $p_{\text {log-rank }}=0.023$; 126.4 vs 24.2 months; Table S8; Figure S22). Similarly, median PFS was better in surgery as first course of treatment ( $p_{\text {log-rank }}=0.042 ; 49.4$ vs 5.8 months; Table S9; Figure S23). A trend to higher risk of progression was also showed in male ( $p_{\text {log-rank }}=0.221 ; 6.9$ vs 6.0 months; Table S9; Figure S24) and stage I, II, IIIA (p log-rank $=0.866 ; 6.5$ vs 4.2 months; Table S9; Figure S25).

\subsection{Genotype distribution}

Genotype frequencies were in agreement with the values expected under the Hardy-Weinberg equilibrium model. Linkage disequilibrium values $D^{\prime}$ and $r^{2}$ are shown in Table S10. No linkage disequilibrium was revealed in any case. The frequencies of these polymorphisms were compared with those reported by HapMap-CEU (Table S11). Significant differences were found for ERCC2 rs13181, ERCC1 rs1799793, MDM2 rs1690927, MTHFR rs1801133 and XRCC1 rs25487 gene polymorphisms.

\subsection{Influence of gene polymorphisms on clinical outcomes of platinum-based chemotherapy}

\subsubsection{Overall population}

\subsubsection{Response}

XRCC1 rs25487 was associated with response. Patients carrying the GG genotype showed significantly better ORR compared to those with AG/AA genotypes (dominant model) $\left(p=0.0343 ; \mathrm{RR}=1.29 ; \mathrm{Cl}_{95 \%}=1.02,1.63\right.$; Table S12). A trend towards better ORR was showed for those patients with ERCC1 rs3212986-GG genotype, but it was not statistically significant (dominant model) $\left(p=0.0825 ; \mathrm{RR}=1.24 ; \mathrm{Cl}_{95 \%}=0.97,1.58\right.$; Table S12). Logistic regression model adjusted by resection revealed that XRCC1 rs25487-GG genotype and ERCC1 rs3212986-GG were independently associated with response ( plikelihood ratio test $=8.663 \cdot 10^{-7}$; Table 2 ).

\subsubsection{Survival}

\subsection{Overall survival}

Kaplan-Meier curve for MDM2 rs1690924 polymorphism showed a trend to higher risk of death for GG genotype, but this was not statistically significant (recessive model) ( $p_{\text {log- }}$ rank $=0.086$; Table S13) (Figure S26). Patients with GG genotype showed a median OS of 17.5 
months $\left(\mathrm{Cl}_{95 \%}=15.2\right.$-Not reached $\left.(\mathrm{NR})\right)$, whereas for $A G$ and $A A$ genotypes was 43.1 $\left(\mathrm{Cl}_{95 \%}=30.7-85.4\right)$ and $32.2\left(\mathrm{Cl}_{95 \%}=24.5-73.9\right)$ months, respectively. Patients with CC genotype for XRCC1 rs1799782 polymorphism showed a trend to higher risk of death compared to those carrying the T-allele, but this was not statistically significant either (dominant model) $\left(p=0.0777 ; \mathrm{HR}=1.88 ; \mathrm{Cl}_{95 \%}=0.93-3.79 ;\right.$ Table S13). The Figure S27 shows the Kaplan-Meier curve in accordance to XRCC1 rs1799782-T allele ( $p_{\text {log-rank }}=0.073$ ). Median OS was 30.0 months $\left(\mathrm{Cl}_{95 \%}=25.4-41.8\right)$ for CC genotype, whereas for CT genotype the median OS was 85.4 months $\left(\mathrm{Cl}_{95 \%}=48.4-\mathrm{NR}\right)$. For the TT genotype, the survival median values exceeded the survival time of the further observation.

Clinical (gender, histology, tumor stage, chemotherapy reagents, surgery) and genetic variables (MDM2 rs1690924 and XRCC1 rs1799782) associated with overall survival were analyzed by multivariate analysis to identify potential confounding effects. Multivariate Cox regression adjusted by gender, tumor histology, chemotherapy agents and surgery revealed that MDM2 rs1690924 gene polymorphism was associated to OS (plikelihood ratio test $=3.391 \cdot 10^{-13}$; Table 3).

\subsection{Progression-free survival}

No associations were demonstrated in the bivariate analysis between polymorphisms and PFS. However, the A-allele for MTR rs 1805087 (recessive model) ( S28) and the AA genotype for SLC19A1 rs1051266 polymorphisms (recessive model) (plogrank $=0.053$ in patients treated with pemetrexed and $p_{\text {log-rank }}=0.127$ in all the patients; Table S14) (Figures S29 and S30) presented a trend to higher risk to progression. Patients with A-allele for MTR rs 1805087 polymorphism showed a median PFS of 12.9 months $\left(\mathrm{Cl}_{95 \%}=10.2-17.6\right)$ versus GG genotype, which revealed a median PFS of 82.3 months $\left(\mathrm{Cl}_{95 \%}=82.3-\mathrm{NR}\right)$. On the other hand, patients treated with pemetrexed showed a median PFS for SLC19A1 rs1051266-AA genotype of 6.05 months $\left(\mathrm{Cl}_{95 \%}=4.27-\mathrm{NR}\right)$, whereas for $\mathrm{G}$-allele the median PFS was 9.07 months $\left(\mathrm{Cl}_{95 \%}=5.2-16.9\right)$. In all the patients median PFS for SLC19A1 rs1051266-AA genotype was 10.1 months $\left(\mathrm{Cl}_{95 \%}=7.0-20.4\right)$, whereas for G-allele the median PFS was 15.0 months $\left(\mathrm{Cl}_{95 \%}=10.9-23.2\right)$.

Clinical (gender, histology, tumor stage, chemotherapy reagents, surgery) and genetic variables (MTR rs1805087 and SLC19A1 rs1051266) associated with progression-free survival were analyzed by multivariate analysis to identify potential confounding effects. Multivariate Cox regression model showed that gender, surgery and concomitant or concurrent radiotherapy were the clinical variables with impact on PFS. MTR rs1805087 and SLC19A1 rs 1051266 were significantly associated with PFS ( plikelihood ratio test $=2.22 \cdot 10^{-16}$; Table 4 )

\subsubsection{Subgroup analysis}

\subsubsection{Response}

In the EGFR native subgroup, carriers of the GG genotype for XRCC1 rs25487 showed significantly better ORR compared to those with AG/AA genotypes, as described in the overall population ( $p=0.0379 ; \mathrm{RR}=1.51 ; \mathrm{Cl}_{95 \%}=1.02,2.23$; Table $\left.\mathrm{S} 15\right)$. Logistic regression model adjusted by tumor stage revealed that XRCC1 rs25487-GG genotype was the only independent factor associated to response in NSCLC patients with native EGFR (Table 5). However, in the subgroup of patients with mutations in EGFR, no association with gene polymorphisms was found (Table S16).

\subsubsection{Survival}

\subsection{Overall survival}

Patients with native EGFR and carriers of the AA genotype for SLC19A1 rs1051266 gene polymorphism were in higher risk of death compared to those with $G$-allele $(p=0.044 ; H R=1.86$; 
$\mathrm{Cl}_{95 \%}=1.02-3.41$; Table S17). Kaplan-Meier curves for OS according to G-allele for SLC19A1 rs1051266 gene polymorphism are showed in Figure S31 ( $p_{\text {log-rank }}=0.041$ ). Median OS for AA carriers was $24.5\left(\mathrm{Cl}_{95 \%}=17.1-32.4\right)$ months, whereas for $\mathrm{G}$-allele was $32.2\left(\mathrm{Cl}_{95 \%}=23.1-85.6\right)$. A trend to higher risk of death was also showed in those patients with native EGFR and GG genotype for the MDM2 rs1690924 gene polymorphism, which was in accordance with the results described in the overall population ( $p=0.283 ; \mathrm{HR}=1.58 ; \mathrm{Cl}_{95 \%}=0.69-3.62$; Table S17). Kaplan-Meier curves for OS according to A-allele for MDM2 rs1690924 gene polymorphism are showed in Figure S32 ( $p_{\text {log-rank }}=0.279$ ). Median OS for patients carrying AA genotype was 25.4 $\left(\mathrm{Cl}_{95 \%}=23.1-\mathrm{NR}\right)$ months, whereas for $\mathrm{AG}$ and $\mathrm{GG}$ genotypes was $30.7\left(\mathrm{Cl}_{95 \%}=15.5-64.7\right)$ and $15.2\left(\mathrm{Cl}_{95 \%}=9.6-\mathrm{NR}\right)$ months, respectively. Multivariate Cox regression adjusted by gender, chemotherapy reagents and tumor resection showed that MDM2 rs1690924 gene polymorphism was the only independent factor associated to OS in NSCLC patients with native

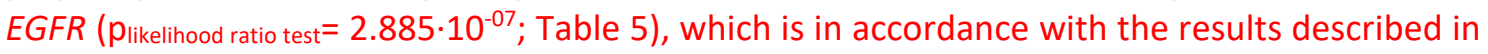
the overall population.

In the subgroup of patients with mutations in EGFR, the bivariate analysis reported that carriers of the ERCC1 rs3212986- T-allele showed higher risk of death, compared to those with GG genotype (dominant model) ( $p=0.0179 ; \mathrm{HR}=4.68$; $\mathrm{Cl}_{95 \%}=1.30-16.76$; Table S18). KaplanMeier curves for OS according to T-allele for ERCC1 rs3212986 gene polymorphism are showed in Figure S33 ( $p_{\text {log-rank }}=0.012$ ). Patients with GG genotype showed a median OS of 30.0 months $\left(\mathrm{Cl}_{95 \%}=30 .-\mathrm{NR}\right)$, whereas for T-allele was 20.9 ( $\left.\mathrm{Cl}_{95 \%}=20.9-\mathrm{NR}\right)$. MTR rs 1805087 was also associated with OS. Patients carrying the AA genotype presented longer OS compared to those carrying the G-allele ( $\mathrm{p}=0.050 ; \mathrm{HR}=3.35 ; \mathrm{Cl}_{95 \%}=1.00-11.23$; Table S18). Kaplan-Meier curves for OS according to MTR rs1805087 gene polymorphism are showed in Figure S34 ( $p_{\text {log-rank }}=0.039$ ). Patients with AA genotype showed a median OS of 52.2 months $\left(\mathrm{Cl}_{95 \%}=21.1-\mathrm{NR}\right)$, whereas for G-allele was 20.9 ( $\mathrm{Cl}_{95 \%}=15.8-\mathrm{NR}$ ). Similarly, the SLC19A rs1051266-G allele was associated with higher risk of death compared to those with AA genotype ( $\mathrm{p}=0.039 ; \mathrm{HR}=9.10 ; \mathrm{Cl}_{95 \%}=1.11-74.46$; Table S18). Kaplan-Meier curves for OS according to G-allele for SLC19A rs1051266 gene polymorphism are showed in Figure $S 35\left(p_{\text {log-rank }}=0.015\right)$. Patients with AA genotype showed a median OS of 105.9 months $\left(\mathrm{Cl}_{95 \%}=30.0-\mathrm{NR}\right)$, whereas for genotype AG was $23.9\left(\mathrm{Cl}_{95 \%}=18.3-\right.$ $\mathrm{NR}$ ), and for $\mathrm{GG}$ was 21.1 ( $\left.\mathrm{Cl}_{95 \%}=15.8-\mathrm{NR}\right)$. However, no association with gene polymorphisms was found in the multivariate Cox regression model.

\subsection{Progression-free survival}

In the subgroup with native EGFR, patients carrying the AC/AA genotype for MTHFR rs 1801131 gene polymorphism were in higher risk of progression, compared to those with CC (recessive model) ( $p=0.050 ; \mathrm{HR}=2.80 ; \mathrm{Cl}_{95 \%}=1.00-7.86$; Table S19). Kaplan-Meier curves for PFS according to A-allele for MTHFR rs1801131 gene polymorphism are showed in Figure S36 ( $p_{\text {log-rank }}=0.041$ ). Patients with CC genotype showed a median PFS of 34.5 months ( $\left.\mathrm{Cl}_{95 \%}=15.5-\mathrm{NR}\right)$, whereas for genotype AC was $10.6\left(\mathrm{Cl}_{95 \%}=6.0-19.6\right)$, and for AA was $9.2\left(\mathrm{Cl}_{95 \%}=7.0-17.1\right)$. MTR rs 1805087 also showed a trend towards higher progression, but this was not statistically significant. In fact, patients carrying the A-allele presented higher risk of progression compared to those carrying the GG genotype ( $p=0.279 ; \mathrm{HR}=2.23 ; \mathrm{Cl}_{95 \%}=0.52-9.57$; Table S19). Kaplan-Meier curves for PFS according to A-allele for MTR rs1805087 gene polymorphism are showed in Figure S37 $\left(p_{\text {log-rank }}=0.269\right)$. Patients with GG genotype showed a median PFS of 82.3 months $\left(\mathrm{Cl}_{95 \%}=2.3\right.$ $\mathrm{NR})$, whereas for A-allele genotype was 10.3 ( $\left.\mathrm{Cl}_{95 \%}=7.7-16.8\right)$. A multivariate Cox regression model adjusted by gender tumor stage, chemotherapy reagents and tumor resection was used to evaluate the impact of gene polymorphisms on PFS (Table 5). MTHFR rs1801131 and MTR rs1805087 gene polymorphism were significantly associated with PFS (plikelihood ratio test= 7.972:10-09).

ERCC1 rs3212986 gene polymorphism showed influence on PFS only in NSCLC patients with mutations in EGFR (Table S20). In fact, patients carrying the GT/TT genotypes presented higher 
risk of progression compared to those carrying the GG genotype $(p=0.0267 ; H R=6.31$; $\mathrm{Cl}_{95 \%}=1.24-32.16$; Table S20). Kaplan-Meier curves for PFS according to T-allele for ERCC1 rs3212986 gene polymorphism is showed in Figure S38 ( $p_{\log \text {-rank }}=0.013$ ). Patients with GG genotype showed a median PFS of 15.6 months ( $\left.\mathrm{Cl}_{95 \%}=6.9-\mathrm{NR}\right)$, whereas for GT and TT genotypes, the median PFS was $5.7\left(\mathrm{Cl}_{95 \%}=3.7-\mathrm{NR}\right)$ and $4.7\left(\mathrm{Cl}_{95 \%}=4.7-\mathrm{NR}\right)$ months, respectively. A trend to higher risk of progression was also showed in those patients with mutations in EGFR and TT genotype for the ERCC2 rs13181 gene polymorphism, but this was not statistically significant (dominant model) ( $\mathrm{p}=0.0758 ; \mathrm{HR}=2.96 ; \mathrm{Cl}_{95 \%}=0.89-9.79 ;$ Table S20). Kaplan-Meier curves for OS according to G-allele for ERCC2 rs13181 gene polymorphism are showed in Figure S39 ( $p_{\text {log-rank }}=0.063$ ). Patients with G-allele genotype showed a median PFS of 6.5 $\left(\mathrm{Cl}_{95 \%}=5.8-\mathrm{NR}\right)$, whereas for TT genotype was 4.9 months $\left(\mathrm{Cl}_{95 \%}=4.2-\mathrm{NR}\right)$. Kaplan-Meier curve for MTR rs 1805087 polymorphism showed a trend to higher risk of progression for AA genotype, but this was not statistically significant ( plog-rank $=0.883$; Table S20) (Figure S40). Patients with AA genotype showed a median OS of 5.8 months $\left(\mathrm{Cl}_{95 \%}=4.2-\mathrm{NR}\right)$, whereas for $\mathrm{G}$ allele was $6.0\left(\mathrm{Cl}_{95 \%}=5.6-\mathrm{NR}\right)$. Multivariate Cox regression adjusted by gender and tumor stage showed that ERCC1 rs3212986, ERCC2 rs13181 and MTR rs1805087 gene polymorphisms were

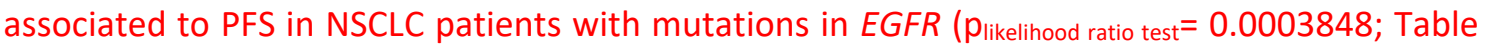
5).

\section{DISCUSSION}

Chemotherapy based on platinum compounds, used as the standard treatment for NSCLC patients with EGFR wild-type, and also as second line in mutated EGFR patients, presents poor clinical outcomes ${ }^{5}$. The inter-individual variability described among patients with the same clinic-pathologic characteristics may be partly explained by genetic factors. Polymorphisms involved in DNA repair pathway and folate metabolism have been proposed as leading cause of these inter-individual differences. In this study, a total of 141 NSCLC patients, treated with platinum compounds in combination with a third-generation drug, were enrolled to evaluate the potential role of ERCC1, ERCC2, XRCC1, MDM2, MTHFR, MTR and SLC19A1 gene polymorphisms in chemotherapy clinical outcomes. ERCC1 rs3212986-GG genotype was associated with better response in our patients (Table 2). Previous studies have reported similar results. In Asian population, two studies with 115 and 163 patients have reported worse $\mathrm{ORR}$ to platinum-based chemotherapy in patients carrying the T-allele $(\mathrm{OR}=0.23$; $\mathrm{Cl}_{95 \%}=0.10,0.57$ for $\mathrm{AC} / \mathrm{AA}$ vs $\mathrm{CC}$ and $\mathrm{OR}=0.44 ; \mathrm{Cl}_{95 \%}=0.27,0.74$ for $\mathrm{T}$ vs $\mathrm{G}$ allele, respectively) ${ }^{56}$, 57. Remarkably, this SNP is located in the $3^{\prime}$-adjacent gene CAST (CD3E-associated signal transducer) and causes an amino acid change in the CAST protein. CAST is an RNA polymerase I-specific subunit and has a role in the activation of transcription ${ }^{58}$. Additionally, it has been suggested that polymerase I may exerts a crucial effect on sensing for DNA damage, indicating a role of CAST in DNA repair ${ }^{59}$. However, whether this polymorphism alters the functional activity of CAST is as yet unknown.

The XRCC1 protein is the key component of the BER pathway, which interacts with DNA polymerase-beta, DNA ligase III and PARP (poly ADP-ribose polymerase), repairing the damaged DNA strand ${ }^{60}$. Although its functional effect has not been well known, XRCC1 rs25487, occurs in the PARP binding domain of XRCC1 gene, may affect complex assembly, and reduce DNA repair efficiency ${ }^{61}$. In our patients, the GG genotype for XRCC1 rs25487 was associated with better ORR compared to those with AG/AA genotypes (Table 2). This result is in consonance with a recent meta-analysis, which evaluated 13 studies and 1334 cases from Asian population (OR=2.05; $\mathrm{Cl}_{95 \%}=1.62,2.60 ; \mathrm{I}^{2}=26 \%$; $\mathrm{P}_{\text {heterogeneity }}=0.18 ; \mathrm{GG}$ vs $\left.\mathrm{AG} / \mathrm{AA}\right){ }^{30}$. However, no significant association had previously been reported in Caucasian patients ${ }^{62-67}$. We also found that patients carrying MDM2 rs1690924-GG genotype were in higher risk to death (Table 3). To date, the functional function of this SNPs is unknown and no other studies have found association between this polymorphism and OS ${ }^{33}$. However, the GG genotype for 
MDM2 rs1690924 has been related to lower gastrointestinal toxicity $\left(\mathrm{OR}=2.32 ; \mathrm{Cl}_{95 \%}=1.30\right.$, 4.14 for $A G$ vs $A A$ ) in 663 Chinese NSCLC patients ${ }^{33}$. In our patients, we also observed that those carrying the MTR rs1805087-A allele or SLC19A1 rs1051266-AA genotype were associated with higher risk of progression (Table 4). The MTR gene plays a crucial function on folate metabolism. Although the direct functional impact of this polymorphism has not been established, there is some evidence that this may be an activating polymorphism; some studies have reported increased enzymatic activity in individuals with GG genotype ${ }^{68}$. Furthermore, individuals with GG genotype have showed lower frequency of CpG island hypermethylation in tumor suppressor genes ${ }^{69}$.To date, no other studies have explored the effect of MTR rs 1805087 on PFS in NSCLC patients treated with platinum-based. However, two studies in $101 \mathrm{IIIB} / \mathrm{IV}$ and $465 \mathrm{I}$ IIV NSCLC patients failed to find an association with response (OR=0.66; $\mathrm{Cl}_{95 \%}=0.23,1.89$ for $\mathrm{AG} / \mathrm{GG}$ vs $\left.\mathrm{AA}\right)$ and $\mathrm{OS}\left(\mathrm{HR}=0.99 ; \mathrm{Cl}_{95 \%}=0.23,1.89\right.$ for $\mathrm{AG} / \mathrm{GG}$ vs AA) ${ }^{35,36}$. The influence of SLC19A1 rs1051266 on clinical outcomes of platinum-based chemotherapy has also been explored, showing no association ${ }^{37-41}$. Our patients with SLC19A1 rs1051266-AA genotype previously showed a greater risk of gastrointestinal toxicity to platinum compounds ${ }^{70}$. However, there is no scientific evidence available of effect of this SNP on protein expression or activity.

In order to confirm if these results were the same considering positive and negative EGFR patients in different groups, a stratified analysis based on EGFR status was performed. The same results as described for all the patients were found in patients with native EGFR. Moreover, an association between PFS and MTHFR rs1801131 polymorphism was observed, which had not been shown for all the patients. In fact, patients with MTHFR rs1801131-A allele were in higher risk of progression compared to those carrying the CC genotype. This result is in consonance with a previous study in 1004 Chinese stage III/IV NSCLC patients that reported lower ORR (OR=1.52; $\mathrm{Cl}_{95 \%}=1.04,2.23$ for $A C$ vs $\left.A A\right)$ and PFS $(p=0.03)$ in patients carrying MTHFR rs1801131-AA genotype ${ }^{71}$. In patients with mutant EGFR, no significant association was found for response and OS, but the ERCC1 rs3212986-T allele, ERCC2 rs13181-TT and MTR rs1805087-AA genotype was associated with shorter PFS (Table 5). The ERCC1 rs3212986 and ERCC2 rs13181 polymorphisms were not associated with PFS when all patients were considered in the analysis. The influence of ERCC1 rs3212986 on survival in NSCLC patients was also reported in previous studies showing shorter OS and PFS in patients carrying the T-allele 56, 72-75. Our results also show the negative effect of ERCC2 rs13181-T allele on PFS, as previously described in 353 Asian stage IIIB/IV NSCLC patients (HR=1.54; $\mathrm{Cl}_{95 \%}=1.03,2.29$ for GT/TT vs GG) ${ }^{76}$. However, a previous meta-analysis including 22 studies/3240 patients reported no association between ORR (OR=0.93; $\mathrm{Cl}_{95 \%}=0.78,1.12 ; \mathrm{I}^{2}=0.0 \%$; Pheterogeneity $=0.707$; $C C / A C$ vs $A A)$ and PFS (HR=1.08; $C_{95 \%}=0.93,1.25 ; I^{2}=28 \% ; P_{\text {heterogeneity }}=0.187 ; A A / A G$ vs GG) ${ }^{28}$. Intriguingly, our results showed a protective effect for advance stage both in native and mutant EGFR (Table 5). However, this effect was not directly because of the stage, but a consequence of the small subgroups sizes, and especially the bad outcome of three patients with stage IIIA, probably affected with a more aggressive tumor, who could not be treated with surgery due to neoadjuvant chemotherapy unresponsiveness. These patients experienced a very rapid progression in less than 4 months, thereby unbalancing the PFS median in the group of early stage (I-IIIA).

The effect of ERCC1 rs11615 on chemotherapy outcomes in NSCLC patients has been extensively investigated, with conflicting results. Some studies have reported better ORR, OS and PFS in patients carrying the CC genotype ${ }^{56,63,72,74,77-84}$, whereas others have described higher ORR, OS and PFS in patients with T-allele 57, 66, 74, 84-89. In our study, ERCC1 rs11615 showed no association neither with response or survival, which is in consonance with the two meta-analysis which have analyzed the compiled results of most of the other studies ${ }^{28,}{ }^{90}$. Previous results for XRCC1 rs1799782 have reported better ORR for T-allele in Asian population, but not in Caucasian patients ${ }^{66,91-96}$. A recent meta-analysis, which involved 11 
studies and compiled 1329 cases, has reported similar results in Asian population (OR=0.38; $\mathrm{Cl}_{95 \%}=0.30,0.48 ; \mathrm{I}^{2}=0 \% ; \mathrm{P}_{\text {heterogeneity }}=0.830 ; \mathrm{CT} / \mathrm{TT}$ vs CC) ${ }^{30}$. No associations between OS, PFS and XRCC1 rs1799782 SNPs have been found ${ }^{66,96-102}$. In our study, this polymorphism, along with ERCC2 rs1799793, was not associated with platinum based chemotherapy outcomes. This lack of association of ERCC2 rs 1799793 with ORR and PFS is in consonance with a previous meta-analysis including 22 studies/3240 patients ${ }^{28}$, which reported no association between ORR (OR=0.87; $\mathrm{Cl}_{95 \%}=0.70,1.08 ; \mathrm{I}^{2}=44.8 \%$; Pheterogeneity $=0.041 ; \mathrm{AA} / \mathrm{AG}$ vs GG) or PFS (HR=1.15; $\mathrm{Cl}_{95 \%}=0.93,1.41 ; I^{2}=24.2 \% ; P_{\text {heterogeneity }}=0.266 ; \mathrm{AA} / \mathrm{AG}$ vs $\left.\mathrm{GG}\right)$. However, this polymorphisms has been associated with OS in several studies ${ }^{63,76,103,104}$. In our study, the MDM2 rs1470383 gene polymorphism was not associated with clinical outcomes of platinum-based chemotherapy. To date, the association between this SNP and response has not been evaluated, being only related to hematological toxicity to chemotherapy in an Asian study with 663 Chinese NSCLC patients (OR=4.10; $\mathrm{Cl}_{95 \%}=1.73,9.71$ ); no association with OS and PFS was found ${ }^{33}$. MTHFR rs1801133 were not associated with clinical outcomes of platinum-based chemotherapy in our patients. Nevertheless, a meta-analysis compiling data from 3 studies and 147 patients, both in Asian and Caucasian populations, has also shown better response in individuals with MTHFR rs1801133-TT genotype (OR=1.72; $C l_{95 \%}=1.01,2.93 ; I^{2}=16 \%$; $P_{\text {heterogeneity }}=0.31 ; T T$ vs CT/CC) ${ }^{34}$. Additionally, the MTHFR rs1801133-TT genotype has also been associated with higher OS $(p=0.026)$ and PFS $(p=0.012)$ in 208 Italian stage IIIB/IV NSCLC patients ${ }^{38}$.

The frequencies of these SNPs in our population were compared with those reported by Hapmap-CEU. Significant differences were found for ERCC2 rs13181, ERCC1 rs1799793, MDM2 rs1690927, MTHFR rs1801133 and XRCC1 rs25487 gene polymorphisms. The reason of these differences may be because these polymorphisms are associated with risk of NSCLC, as it is described in several meta-analysis ${ }^{34,105-107 .}$

The limitations of our study include a limited sample size and a considerable number of genetic and clinical covariates that may have reduced the group sizes for some comparisons, which may be responsible of the lack of association between some polymorphisms. However, the recruitment of a single hospital cohort, following the same therapeutic protocols by the same team of oncologists ensured its homogeneity and reliability of the response variables. All patients diagnosed during the period of study were recruited, ensuring the representativeness of the sample. Despite the limited sample size, the effects observed in these patients were evident. Further studies in larger cohorts will be necessary to confirm the predictive value of some of the biomarkers, particularly ERCC1, XRCC1, MDM2, MTR and SLC19A1 gene polymorphisms in the management of NSCLC patients.

In summary, these results showed that ERCC1 rs3212986, XRCC1 rs25487, MDM2 rs1690924, MTR rs1805087, SLC19A1 rs1051266 gene polymorphisms may significantly act as predictive factors in NSCLC patients treated with platinum-based chemotherapy.

\section{CONCLUSIONS}

Our results suggest that ERCC1 rs3212986-GG and XRCC1 rs25487-GG genotypes are associated with better ORR. NSCLC patients carrying the MDM2 rs1690924-GG genotype were in higher risk of death. The MTR rs1805087-A alleles and the SLC19A1 rs1051266-AA genotype were associated with greater risk of progression. No association between ERCC1 rs11615, ERCC2 rs13181, ERCC2 rs1799793, XRCC1 rs1799782, MDM2 rs1470383, MTHFR rs1801131, MTHFR rs1801133 and clinical outcomes of platinum-based chemotherapy was found in our patients.

\section{AUTHOR CONTRIBUTIONS}

Cristina Pérez-Ramírez revised the bibliography and wrote the protocol for this study and acted as the primary lead in the conception, design and implementation of the project, data 
collection, molecular analysis, statistical analysis and interpretation, as well as all aspects of the development and writing of the article and responses to internal and external reviewers.

Marisa Cañadas-Garre, PhD, supervised the planning of the study protocol and contributed to the conception, design and implementation of the project, statistical analysis and interpretation as well as all aspects of the development and writing of the article and responses to internal and external reviewers.

Ahmed Alnatsha performed literature review, molecular analysis and interpretation, clinical data collection and interpretation and collaborated in drafting the manuscript.

Eduardo Villar, MD, PhD, performed molecular and pathological analysis and interpretation, clinical data collection and interpretation and collaborated in drafting the manuscript.

Javier Valdivia Bautista, MD participated in the clinical data collection and interpretation, and provided clinical guidance and feedback for this study and critical review of the manuscript.

María José Faus-Dáder, PhD and Miguel Ángel Calleja-Hernández, PhD, participated in article selection, study quality assessment, critical review of the manuscript and contributed to revisions and responses to internal and external reviewers.

\section{REFERENCES}

1. Siegel RL, Miller KD, Jemal A. Cancer statistics, 2016. CA: a cancer journal for clinicians 2016; 66(1): 7-30.

2. Edge S, Byrd, D.R., Compton, C.C., Fritz, A.G., Greene, F.L., Trotti, A. AJCC Cancer Staging Manual, 7th edn, 2010.

3. Herbst RS HJ, Lippman SM. Lung cancer. N Engl J Med 2008; 359(13): 1367-1380.

4. Molina JR, Yang P, Cassivi SD, Schild SE, Adjei AA. Non-small cell lung cancer: epidemiology, risk factors, treatment, and survivorship. Mayo Clinic proceedings 2008; 83(5): 584-594.

5. Ettinger DS, Wood DE, Akerley W, Bazhenova LA, Borghaei H, Camidge DR, et al. NCCN Guidelines Insights: Non-Small Cell Lung Cancer, Version 4.2016. Journal of the National Comprehensive Cancer Network : JNCCN 2016; 14(3): 255-264.

6. Brule SY, Al-Baimani K, Jonker H, Zhang T, Nicholas G, Goss G, et al. Palliative systemic therapy for advanced non-small cell lung cancer: Investigating disparities between patients who are treated versus those who are not. Lung cancer 2016; 97: 15-21.

7. Zhong $\mathrm{C}$, Liu H, Jiang L, Zhang W, Yao F. Chemotherapy plus best supportive care versus best supportive care in patients with non-small cell lung cancer: a meta-analysis of randomized controlled trials. PloS one 2013; 8(3): e58466.

8. Blumenthal GM, Karuri SW, Zhang H, Zhang L, Khozin S, Kazandjian D, et al. Overall response rate, progression-free survival, and overall survival with targeted and 
standard therapies in advanced non-small-cell lung cancer: US Food and Drug Administration trial-level and patient-level analyses. J Clin Oncol 2015; 33(9): 10081014.

9. Cardenal F, Lopez-Cabrerizo MP, Anton A, Alberola V, Massuti B, Carrato A, et al. Randomized phase III study of gemcitabine-cisplatin versus etoposide-cisplatin in the treatment of locally advanced or metastatic non-small-cell lung cancer. J Clin Oncol 1999; 17(1): 12-18.

10. Choi MK, Hong JY, Chang W, Kim M, Kim S, Jung HA, et al. Safety and efficacy of gemcitabine or pemetrexed in combination with a platinum in patients with non-smallcell lung cancer and prior interstitial lung disease. Cancer chemotherapy and pharmacology 2014; 73(6): 1217-1225.

11. Crino L, Weder W, van Meerbeeck J, Felip E. Early stage and locally advanced (nonmetastatic) non-small-cell lung cancer: ESMO Clinical Practice Guidelines for diagnosis, treatment and follow-up. Annals of oncology : official journal of the European Society for Medical Oncology / ESMO 2010; 21 Suppl 5: v103-115.

12. Fenchel K, Sellmann L, Dempke WC. Overall survival in non-small cell lung cancer-what is clinically meaningful? Trans/ Lung Cancer Res 2016; 5(1): 115-119.

13. Gervais R, Robinet G, Clement-Duchene C, Denis F, El Kouri C, Martin P, et al. Pemetrexed and carboplatin, an active option in first-line treatment of elderly patients with advanced non-small cell lung cancer (NSCLC): a phase II trial. Lung cancer 2013; 80(2): 185-190.

14. Hasegawa Y, Miura D, Kitamura C, Suzuki T, Kobayashi K, Sato N. A randomized phase II trial of gemcitabine plus carboplatin: biweekly versus standard schedules in patients with advanced non-small cell lung cancer. Chemotherapy 2013; 59(5): 346-353.

15. Ichiki M, Kawasaki M, Takayama K, Ninomiya K, Kuba M, Iwami F, et al. A multicenter phase II study of carboplatin and paclitaxel with a biweekly schedule in patients with advanced non-small-cell lung cancer: Kyushu thoracic oncology group trial. Cancer chemotherapy and pharmacology 2006; 58(3): 368-373.

16. Karampeazis A, Vamvakas L, Kentepozidis N, Polyzos A, Chandrinos V, Rigas G, et al. Biweekly Carboplatin Plus Gemcitabine as First-Line Treatment of Elderly Patients With Advanced Squamous Non-Small-cell Lung Cancer: A Multicenter Phase I-II Trial by the Hellenic Oncology Research Group. Clinical lung cancer 2016.

17. $\operatorname{Kim~HJ,~Kim~TG,~Lee~HJ,~Kim~JH,~Lim~BH,~Seo~JW,~et~al.~A~phase~Il~study~of~combination~}$ chemotherapy with docetaxel and carboplatin for elderly patients with advanced nonsmall cell lung cancer. Lung cancer 2010; 68(2): 248-252. 
18. Maemondo M, Inoue A, Kobayashi K, Sugawara S, Oizumi S, Isobe H, et al. Gefitinib or chemotherapy for non-small-cell lung cancer with mutated EGFR. The New England journal of medicine 2010; 362(25): 2380-2388.

19. Schuette WH, Groschel A, Sebastian M, Andreas S, Muller T, Schneller F, et al. A randomized phase II study of pemetrexed in combination with cisplatin or carboplatin as first-line therapy for patients with locally advanced or metastatic non-small-cell lung cancer. Clinical lung cancer 2013; 14(3): 215-223.

20. Soejima K, Naoki K, Ishioka K, Nakamura M, Nakatani M, Kawada I, et al. A phase II study of biweekly paclitaxel and carboplatin in elderly patients with advanced nonsmall cell lung cancer. Cancer chemotherapy and pharmacology 2015; 75(3): 513-519.

21. Takatani H, Nakamura Y, Nagashima S, Soda H, Kinoshita A, Fukuda M, et al. Phase I and II trials of vinorelbine with carboplatin for patients 75 years of age or older with previously untreated non-small-cell lung cancer. Clinical lung cancer 2012; 13(5): 347351.

22. Belani CP, Einzig A, Bonomi P, Dobbs T, Capozzoli MJ, Earhart R, et al. Multicenter phase II trial of docetaxel and carboplatin in patients with stage IIIB and IV non-smallcell lung cancer. Annals of oncology : official journal of the European Society for Medical Oncology / ESMO 2000; 11(6): 673-678.

23. Ozkaya S, Findik S, Atici AG, Dirica A. Cisplatin-based chemotherapy in elderly patients with advanced stage (IIIB and IV) non-small cell lung cancer patients. Neoplasma 2011; 58(4): 348-351.

24. Ozkaya S, Findik S, Dirican A, Atici AG. Long-term survival rates of patients with stage IIIB and IV non-small cell lung cancer treated with cisplatin plus vinorelbine or gemcitabine. Experimental and therapeutic medicine 2012; 4(6): 1035-1038.

25. Li T, Kung HJ, Mack PC, Gandara DR. Genotyping and genomic profiling of non-smallcell lung cancer: implications for current and future therapies. J Clin Oncol 2013; 31(8): 1039-1049.

26. Wei HB, Lu XS, Shang LH, Xu G, Hu J, Che DH, et al. Polymorphisms of ERCC1 $\mathrm{C} 118 \mathrm{~T} / \mathrm{C} 8092 \mathrm{~A}$ and MDR1 C3435T predict outcome of platinum-based chemotherapies in advanced non-small cell lung cancer: a meta-analysis. Archives of medical research 2011; 42(5): 412-420.

27. Wei SZ, Zhan P, Shi MQ, Shi Y, Qian Q, Yu LK, et al. Predictive value of ERCC1 and XPD polymorphism in patients with advanced non-small cell lung cancer receiving 
platinum-based chemotherapy: a systematic review and meta-analysis. Med Oncol 2011; 28(1): 315-321.

28. Yang $\mathrm{Y}$, Xian $\mathrm{L}$. The association between the ERCC1/2 polymorphisms and the clinical outcomes of the platinum-based chemotherapy in non-small cell lung cancer (NSCLC): a systematic review and meta-analysis. Tumour biology : the journal of the International Society for Oncodevelopmental Biology and Medicine 2014; 35(4): 29052921.

29. Huang SJ, Wang YF, Jin ZY, Sun JY, Guo ZL. Role of ERCC1 variants in response to chemotherapy and clinical outcome of advanced non-small cell lung cancer. Tumour biology : the journal of the International Society for Oncodevelopmental Biology and Medicine 2014; 35(5): 4023-4029.

30. Li L, Wan C, Wen FQ. Polymorphisms in the XRCC1 gene are associated with treatment response to platinum chemotherapy in advanced non-small cell lung cancer patients based on meta-analysis. Genetics and molecular research : GMR 2014; 13(2): 37723786.

31. Shen XY, Lu FZ, Wu Y, Zhao LT, Lin ZF. XRCC3 Thr241Met polymorphism and clinical outcomes of NSCLC patients receiving platinum-based chemotherapy: a systematic review and meta-analysis. PloS One 2013; 8(8): e69553.

32. Shiraishi K, Kohno T, Tanai C, Goto Y, Kuchiba A, Yamamoto S, et al. Association of DNA repair gene polymorphisms with response to platinum-based doublet chemotherapy in patients with non-small-cell lung cancer. J Clin Oncol 2010; 28(33): 4945-4952.

33. Qian J, Liu H, Gu S, Wu Q, Zhao X, Wu W, et al. Genetic Variants of the MDM2 Gene Are Predictive of Treatment-Related Toxicities and Overall Survival in Patients With Advanced NSCLC. Clinical lung cancer 2015; 16(5): e37-53.

34. Zhu N, Gong Y, He J, Xia J, Chen X. Influence of methylenetetrahydrofolate reductase C677T polymorphism on the risk of lung cancer and the clinical response to platinumbased chemotherapy for advanced non-small cell lung cancer: an updated metaanalysis. Yonsei medical journal 2013; 54(6): 1384-1393.

35. Cui LH YZ, Zhang TT, Shin MH, Kim HN, Choi JS. Influence of polymorphisms in MTHFR $677 \mathrm{C} \rightarrow \mathrm{T}$, TYMS $3 R \rightarrow 2 R$ and MTR $2756 \mathrm{~A} \rightarrow \mathrm{G}$ on NSCLC risk and response to platinumbased chemotherapy in advanced NSCLC. Pharmacogenomics 2011; 12(6): 797-808.

36. Matakidou A, El Galta R, Rudd MF, Webb EL, Bridle H, Eisen T, et al. Prognostic significance of folate metabolism polymorphisms for lung cancer. British journal of cancer 2007; 97(2): 247-252. 
37. Li WJ, Jiang H, Fang XJ, Ye HL, Liu MH, Liu YW, et al. Polymorphisms in thymidylate synthase and reduced folate carrier () genes predict survival outcome in advanced non-small cell lung cancer patients treated with pemetrexed-based chemotherapy. Oncology letters 2013; 5(4): 1165-1170.

38. Tiseo M, Giovannetti E, Tibaldi C, Camerini A, Di Costanzo F, Barbieri F, et al. Pharmacogenetic study of patients with advanced non-small cell lung cancer (NSCLC) treated with second-line pemetrexed or pemetrexed-carboplatin. Lung cancer 2012; 78(1): 92-99.

39. Corrigan A, Walker JL, Wickramasinghe S, Hernandez MA, Newhouse SJ, Folarin AA, et al. Pharmacogenetics of pemetrexed combination therapy in lung cancer: pathway analysis reveals novel toxicity associations. The pharmacogenomics journal 2014; 14(5): 411-417.

40. Smit EF, Burgers SA, Biesma B, Smit HJ, Eppinga P, Dingemans AM, et al. Randomized phase II and pharmacogenetic study of pemetrexed compared with pemetrexed plus carboplatin in pretreated patients with advanced non-small-cell lung cancer. J Clin Oncol 2009; 27(12): 2038-2045.

41. Adjei AA, Salavaggione OE, Mandrekar SJ, Dy GK, Ziegler KL, Endo C, et al. Correlation between polymorphisms of the reduced folate carrier gene (SLC19A1) and survival after pemetrexed-based therapy in non-small cell lung cancer: a North Central Cancer Treatment Group-based exploratory study. Journal of thoracic oncology : official publication of the International Association for the Study of Lung Cancer 2010; 5(9): 1346-1353.

42. Perez-Ramirez C, Canadas-Garre M, Alnatsha A, Villar E, Delgado JR, Faus-Dader MJ, et al. Pharmacogenetic predictors of toxicity to platinum based chemotherapy in nonsmall cell lung cancer patients. Pharmacological research 2016; 111: 877-884.

43. Kartalou M, Essigmann JM. Recognition of cisplatin adducts by cellular proteins. Mutation research 2001; 478(1-2): 1-21.

44. Jordan P, Carmo-Fonseca M. Molecular mechanisms involved in cisplatin cytotoxicity. Cell Mol Life Sci 2000; 57(8-9): 1229-1235.

45. Sancar A. DNA repair in humans. Annu Rev Genet 1995; 29: 69-105.

46. Garcia-Campelo R, Alonso-Curbera G, Anton Aparicio LM, Rosell R. Pharmacogenomics in lung cancer: an analysis of DNA repair gene expression in patients treated with platinum-based chemotherapy. Expert Opin Pharmacother 2005; 6(12): 2015-2026. 
47. Jin S, Levine AJ. The p53 functional circuit. Journal of cell science 2001; 114(Pt 23): 4139-4140.

48. Michael D, Oren M. The p53-Mdm2 module and the ubiquitin system. Semin Cancer Biol 2003; 13(1): 49-58.

49. Azzoli CG, Baker S, Temin S, Pao W, Aliff T, Brahmer J, et al. American Society of Clinical Oncology clinical practice guideline update on chemotherapy for stage IV nonsmall-cell lung cancer. J Clin Oncol 2009; 27(36): 6251-6266.

50. Benlloch S, Botero ML, Beltran-Alamillo J, Mayo C, Gimenez-Capitan A, de Aguirre I, et al. Clinical validation of a PCR assay for the detection of EGFR mutations in non-smallcell lung cancer: retrospective testing of specimens from the EURTAC trial. PloS One 2014; 9(2): e89518.

51. Edge SB BR, Compton CC, Fritz AG, Green FL, Trotti A, editors. AJCC Cancer Staging Manual. 7 ed. Springer-Verlag New York 2010: pp. XV-648.

52. Jimenez-Varo E, Canadas-Garre M, Henriques $\mathrm{Cl}$, Pinheiro AM, Gutierrez-Pimentel MJ, Calleja-Hernandez MA. Pharmacogenetics role in the safety of acenocoumarol therapy. Thrombosis and haemostasis 2014; 112(3): 522-536.

53. Eisenhauer EA, Therasse P, Bogaerts J, Schwartz LH, Sargent D, Ford R, et al. New response evaluation criteria in solid tumours: revised RECIST guideline (version 1.1). European journal of cancer (Oxford, England : 1990) 2009; 45(2): 228-247.

54. Purcell S, Neale B, Todd-Brown K, Thomas L, Ferreira MAR, Bender D, et al. PLINK: a toolset for whole-genome association and population-based linkage analysis. American journal of human genetics 2007; 81.

55. Team RC. R: A language and environment for statistical computing. [Internet]. 2013 Oct. Available from: http://www.r-project.org/.

56. Gao H, Ge RC, Liu HY, Wang Y, Yan S. Effect of ERCC1 polymorphism on the response to chemotherapy and clinical outcome of non-small cell lung cancer. Genetics and molecular research : GMR 2014; 13(4): 8997-9004.

57. Li F, Sun X, Sun N, Qin S, Cheng H, Feng J, et al. Association between polymorphisms of ERCC1 and XPD and clinical response to platinum-based chemotherapy in advanced non-small cell lung cancer. Am J Clin Oncol 2010; 33(5): 489-494. 
58. Panov KI, Panova TB, Gadal O, Nishiyama K, Saito T, Russell J, et al. RNA polymerase Ispecific subunit CAST/hPAF49 has a role in the activation of transcription by upstream binding factor. Molecular and cellular biology 2006; 26(14): 5436-5448.

59. Russell J, Zomerdijk JC. RNA-polymerase-I-directed rDNA transcription, life and works. Trends in biochemical sciences 2005; 30(2): 87-96.

60. Whitehouse CJ, Taylor RM, Thistlethwaite A, Zhang H, Karimi-Busheri F, Lasko DD, et al. XRCC1 stimulates human polynucleotide kinase activity at damaged DNA termini and accelerates DNA single-strand break repair. Cell 2001; 104(1): 107-117.

61. Park JY, Lee SY, Jeon HS, Bae NC, Chae SC, Joo S, et al. Polymorphism of the DNA repair gene XRCC1 and risk of primary lung cancer. Cancer epidemiology, biomarkers \& prevention : a publication of the American Association for Cancer Research, cosponsored by the American Society of Preventive Oncology 2002; 11(1): 23-27.

62. Giachino DF, Ghio P, Regazzoni S, Mandrile G, Novello S, Selvaggi G, et al. Prospective assessment of XPD Lys751GIn and XRCC1 Arg399GIn single nucleotide polymorphisms in lung cancer. Clinical cancer research : an official journal of the American Association for Cancer Research 2007; 13(10): 2876-2881.

63. Joerger M, Burgers SA, Baas P, Smit EF, Haitjema TJ, Bard MP, et al. Germline polymorphisms in patients with advanced nonsmall cell lung cancer receiving first-line platinum-gemcitabine chemotherapy: a prospective clinical study. Cancer 2012; 118(9): 2466-2475.

64. Kalikaki A, Kanaki M, Vassalou H, Souglakos J, Voutsina A, Georgoulias V, et al. DNA repair gene polymorphisms predict favorable clinical outcome in advanced non-smallcell lung cancer. Clinical lung cancer 2009; 10(2): 118-123.

65. Kalikaki A, Voutsina A, Koutsopoulos A, Papadaki C, Sfakianaki M, Yachnakis E, et al. ERCC1 SNPs as Potential Predictive Biomarkers in Non-Small Cell Lung Cancer Patients Treated With Platinum-Based Chemotherapy. Cancer investigation 2015; 33(4): 107113.

66. Sullivan I, Salazar J, Majem M, Pallares C, Del Rio E, Paez D, et al. Pharmacogenetics of the DNA repair pathways in advanced non-small cell lung cancer patients treated with platinum-based chemotherapy. Cancer letters 2014; 353(2): 160-166.

67. Tiseo M, Bordi P, Bortesi B, Boni L, Boni C, Baldini E, et al. ERCC1/BRCA1 expression and gene polymorphisms as prognostic and predictive factors in advanced NSCLC treated with or without cisplatin. British journal of cancer 2013; 108(8): 1695-1703. 
68. Goode EL, Potter JD, Bigler J, Ulrich CM. Methionine synthase D919G polymorphism, folate metabolism, and colorectal adenoma risk. Cancer epidemiology, biomarkers \& prevention : a publication of the American Association for Cancer Research, cosponsored by the American Society of Preventive Oncology 2004; 13(1): 157-162.

69. Paz MF, Avila S, Fraga MF, Pollan M, Capella G, Peinado MA, et al. Germ-line variants in methyl-group metabolism genes and susceptibility to DNA methylation in normal tissues and human primary tumors. Cancer research 2002; 62(15): 4519-4524.

70. Perez-Ramirez C, Canadas-Garre M, Alnatsha A, Villar E, Delgado JR, Faus-Dader MJ, et al. Pharmacogenetic predictors of toxicity to platinum based chemotherapy in nonsmall cell lung cancer patients. Pharmacol Res 2016;Submitted.

71. Li X, Shao M, Wang S, Zhao X, Chen H, Qian J, et al. Heterozygote advantage of methylenetetrahydrofolate reductase polymorphisms on clinical outcomes in advanced non-small cell lung cancer (NSCLC) patients treated with platinum-based chemotherapy. Tumour biology : the journal of the International Society for Oncodevelopmental Biology and Medicine 2014; 35(11): 11159-11170.

72. Okuda K, Sasaki H, Hikosaka Y, Kawano O, Yukiue H, Yano M, et al. Excision repair cross complementation group 1 polymorphisms predict overall survival after platinum-based chemotherapy for completely resected non-small-cell lung cancer. The Journal of surgical research 2011; 168(2): 206-212.

73. Takenaka T, Yano T, Kiyohara C, Miura N, Kouso H, Ohba T, et al. Effects of excision repair cross-complementation group 1 (ERCC1) single nucleotide polymorphisms on the prognosis of non-small cell lung cancer patients. Lung cancer 2010; 67(1): 101-107.

74. Zhao X, Zhang Z, Yuan Y, Yuan X. Polymorphisms in ERCC1 gene could predict clinical outcome of platinum-based chemotherapy for non-small cell lung cancer patients. Tumour biology : the journal of the International Society for Oncodevelopmental Biology and Medicine 2014; 35(8): 8335-8341.

75. Zhou W, Gurubhagavatula S, Liu G, Park S, Neuberg DS, Wain JC, et al. Excision repair cross-complementation group 1 polymorphism predicts overall survival in advanced non-small cell lung cancer patients treated with platinum-based chemotherapy. Clinical cancer research : an official journal of the American Association for Cancer Research 2004; 10(15): 4939-4943.

76. Wu W, Li H, Wang H, Zhao X, Gao Z, Qiao R, et al. Effect of polymorphisms in XPD on clinical outcomes of platinum-based chemotherapy for Chinese non-small cell lung cancer patients. PloS One 2012; 7(3): e33200. 
77. Su D, Ma S, Liu P, Jiang Z, Lv W, Zhang Y, et al. Genetic polymorphisms and treatment response in advanced non-small cell lung cancer. Lung cancer 2007; 56(2): 281-288.

78. Cheng J, Ha M, Wang Y, Sun J, Chen J, Wang Y, et al. A C118T polymorphism of ERCC1 and response to cisplatin chemotherapy in patients with late-stage non-small cell lung cancer. Journal of cancer research and clinical oncology 2012; 138(2): 231-238.

79. Dong J, Hu Z, Shu Y, Pan S, Chen W, Wang Y, et al. Potentially functional polymorphisms in DNA repair genes and non-small-cell lung cancer survival: a pathway-based analysis. Molecular carcinogenesis 2012; 51(7): 546-552.

80. Isla D, Sarries C, Rosell R, Alonso G, Domine M, Taron M, et al. Single nucleotide polymorphisms and outcome in docetaxel-cisplatin-treated advanced non-small-cell lung cancer. Annals of oncology : official journal of the European Society for Medical Oncology / ESMO 2004; 15(8): 1194-1203.

81. Park SY, Hong YC, Kim JH, Kwak SM, Cho JH, Lee HL, et al. Effect of ERCC1 polymorphisms and the modification by smoking on the survival of non-small cell lung cancer patients. Med Oncol 2006; 23(4): 489-498.

82. Ryu JS, Hong YC, Han HS, Lee JE, Kim S, Park YM, et al. Association between polymorphisms of ERCC1 and XPD and survival in non-small-cell lung cancer patients treated with cisplatin combination chemotherapy. Lung cancer 2004; 44(3): 311-316.

83. Krawczyk P, Wojas-Krawczyk K, Mlak R, Kucharczyk T, Biernacka B, Milanowski J. Predictive value of ERCC1 single-nucleotide polymorphism in patients receiving platinum-based chemotherapy for locally-advanced and advanced non-small cell lung cancer--a pilot study. Folia histochemica et cytobiologica / Polish Academy of Sciences, Polish Histochemical and Cytochemical Society 2012; 50(1): 80-86.

84. Lv H, Han T, Shi X, Yao Y, Yao Y, Qiu W, et al. Genetic polymorphism of GSTP1 and ERCC1 correlated with response to platinum-based chemotherapy in non-small cell lung cancer. Med Oncol 2014; 31(8): 86.

85. Du Y, Su T, Zhao L, Tan X, Chang W, Zhang H, et al. Associations of polymorphisms in DNA repair genes and MDR1 gene with chemotherapy response and survival of nonsmall cell lung cancer. PloS One 2014; 9(6): e99843.

86. Shi ZH, Shi GY, Liu LG. Polymorphisms in ERCC1 and XPF gene and response to chemotherapy and overall survival of non-small cell lung cancer. International journal of clinical and experimental pathology 2015; 8(3): 3132-3137. 
87. Zhou C, Ren S, Zhou S, Zhang L, Su C, Zhang Z, et al. Predictive effects of ERCC1 and XRCC3 SNP on efficacy of platinum-based chemotherapy in advanced NSCLC patients. Japanese journal of clinical oncology 2010; 40(10): 954-960.

88. Ren S, Zhou S, Wu F, Zhang L, Li X, Zhang J, et al. Association between polymorphisms of DNA repair genes and survival of advanced NSCLC patients treated with platinumbased chemotherapy. Lung cancer 2012; 75(1): 102-109.

89. Wang J, Zhang Q, Zhang H, Wang Q, Yang X, Gu Y, et al. [Association between polymorphisms of ERCC1 and response in patients with advanced non-small cell lung cancer receiving cisplatin-based chemotherapy]. Zhongguo fei ai za zhi $=$ Chinese journal of lung cancer 2010; 13(4): 337-341.

90. Huang D, Zhou Y. Nucleotide excision repair gene polymorphisms and prognosis of non-small cell lung cancer patients receiving platinum-based chemotherapy: A metaanalysis based on 44 studies. Biomedical reports 2014; 2(4): 452-462.

91. Hong $\mathrm{CY}, \mathrm{Xu} \mathrm{Q}$, Yue Z, Zhang Y, Yuan Y. [Correlation of the sensitivity of NP chemotherapy in non-small lung cancer with DNA repair gene XRCC1 polymorphism]. Ai zheng $=$ Aizheng $=$ Chinese journal of cancer 2009; 28(12): 1291-1297.

92. Sun X, Li F, Sun N, Shukui Q, Baoan C, Jifeng F, et al. Polymorphisms in XRCC1 and XPG and response to platinum-based chemotherapy in advanced non-small cell lung cancer patients. Lung cancer 2009; 65(2): 230-236.

93. Wang ZH, Miao XP, Tan W, Zhang XR, Xu BH, Lin DX. [Single nucleotide polymorphisms in XRCC1 and clinical response to platin-based chemotherapy in advanced non-small cell lung cancer]. Ai zheng = Aizheng = Chinese journal of cancer 2004; 23(8): 865-868.

94. Xu C, Wang X, Zhang Y, Li L. [Effect of the XRCC1 and XRCC3 genetic polymorphisms on the efficacy of platinum-based chemotherapy in patients with advanced non-small cell lung cancer]. Zhongguo fei ai za zhi = Chinese journal of lung cancer 2011; 14(12): 912917.

95. Yuan $\mathrm{P}$, Miao XP, Zhang XM, Wang ZH, Tan W, Sun Y, et al. [XRCC1 and XPD genetic polymorphisms predict clinical responses to platinum-based chemotherapy in advanced non-small cell lung cancer]. Zhonghua zhong liu za zhi [Chinese journal of oncology] 2006; 28(3): 196-199.

96. Powrozek T, Mlak R, Krawczyk P, Homa I, Ciesielka M, Koziol P, et al. The relationship between polymorphisms of genes regulating DNA repair or cell division and the toxicity of platinum and vinorelbine chemotherapy in advanced NSCLC patients. Clinical \& translational oncology : official publication of the Federation of Spanish Oncology Societies and of the National Cancer Institute of Mexico 2015. 
97. Ke HG, Li J, Shen Y, You QS, Yan Y, Dong HX, et al. Prognostic significance of GSTP1, XRCC1 and XRCC3 polymorphisms in non-small cell lung cancer patients. Asian Pacific journal of cancer prevention : APJCP 2012; 13(9): 4413-4416.

98. Zhang L, Ma W, Li Y, Wu J, Shi GY. Pharmacogenetics of DNA repair gene polymorphisms in non-small-cell lung carcinoma patients on platinum-based chemotherapy. Genetics and molecular research : GMR 2014; 13(1): 228-236.

99. Zhao W, Hu L, Xu J, Shen H, Hu Z, Ma H, et al. Polymorphisms in the base excision repair pathway modulate prognosis of platinum-based chemotherapy in advanced non-small cell lung cancer. Cancer chemotherapy and pharmacology 2013; 71(5): 1287-1295.

100. Han B, Guo Z, Ma Y, Kang S, Wang Y, Wei Q, et al. Association of GSTP1 and XRCC1 gene polymorphisms with clinical outcome of advanced non-small cell lung cancer patients with cisplatin-based chemotherapy. International journal of clinical and experimental pathology 2015; 8(4): 4113-4119.

101. Liu JY, Liu QM, Li LR. Association of GSTP1 and XRCC1 gene polymorphisms with clinical outcomes of patients with advanced non-small cell lung cancer. Genetics and molecular research : GMR 2015; 14(3): 10331-10337.

102. Liu D, Wu J, Shi GY, Zhou HF, Yu Y. Role of XRCC1 and ERCC5 polymorphisms on clinical outcomes in advanced non-small cell lung cancer. Genetics and molecular research : GMR 2014; 13(2): 3100-3107.

103. Liao WY, Shih JY, Chang GC, Cheng YK, Yang JC, Chen YM, et al. Genetic polymorphism of XRCC1 Arg399GIn is associated with survival in non-small-cell lung cancer patients treated with gemcitabine/platinum. Journal of thoracic oncology : official publication of the International Association for the Study of Lung Cancer 2012; 7(6): 973-981.

104. Zhou M, Ding YJ, Feng Y, Zhang QR, Xiang Y, Wan HY. Association of xeroderma pigmentosum group D (Asp312Asn, Lys751GIn) and cytidine deaminase (Lys27GIn, Ala70Thr) polymorphisms with outcome in Chinese non-small cell lung cancer patients treated with cisplatin-gemcitabine. Genetics and molecular research : GMR 2014; 13(2): 3310-3318.

105. Tan X, Xian L, Chen X, Shi L, Wang Y, Guo J, et al. Association between ERCC2 Lys $751 \mathrm{Gln}$ polymorphism and lung cancer risk: a meta-analysis involving 23,370 subjects. Twin research and human genetics : the official journal of the International Society for Twin Studies 2014; 17(2): 99-107. 
106. Zhan P, Wang Q, Wei SZ, Wang J, Qian Q, Yu LK, et al. ERCC2/XPD Lys751GIn and Asp312Asn gene polymorphism and lung cancer risk: a meta-analysis involving 22 case-control studies. J Thorac Oncol 2010; 5(9): 1337-1345.

107. Wang Y, Yang H, Li H, Li L, Wang H, Liu C, et al. Association between X-ray repair cross complementing group 1 codon 399 and 194 polymorphisms and lung cancer risk: a meta-analysis. Cancer letters 2009; 285(2): 134-140.

\section{FIGURE LEGENDS}

Figure S1. A) Kaplan-Meier curve for overall survival according to gender in 141 NSCLC patients. B) Kaplan-Meier curve for overall survival according to histology in 141 NSCLC patients. C) Kaplan-Meier curve for overall survival according to tumor stage in in 141 NSCLC patients. D) Kaplan-Meier curve for overall survival according to chemotherapy reagents in 141 NSCLC patients. E) Kaplan-Meier curve for overall survival according to surgery in 141 NSCLC patients.

Figure S2. A) Kaplan-Meier curve for progression-free survival according to gender in 141 NSCLC patients. B) Kaplan-Meier curve for progression-free survival according to histology in 141 NSCLC patients. C) Kaplan-Meier curve for progression-free survival according to tumor stage in 141 NSCLC patients. D) Kaplan-Meier curve for progression-free survival according to chemotherapy reagents in 141 NSCLC patients. E) Kaplan-Meier curve for progression-free survival according to surgery in 141 NSCLC patients. F) Kaplan-Meier curve for progression-free survival according to concomitant or concurrent radiotherapy in 141 NSCLC patients.

Figure S3. A) Kaplan-Meier curve for overall survival according to gender in patients with native EGFR. B) Kaplan-Meier curve for overall survival according to personal history of cancer in patients with native EGFR. C) Kaplan-Meier curve for overall survival according to tumor stage in patients with native EGFR. D) Kaplan-Meier curve for overall survival according to chemotherapy reagents in patients with native EGFR. E) Kaplan-Meier curve for overall survival according to surgery in patients with native EGFR.

Figure S4. A) Kaplan-Meier curve for progression-free survival according to gender in patients with native EGFR. B) Kaplan-Meier curve for progression-free survival according to tumor stage in patients with native EGFR. C) Kaplan-Meier curve for progression-free survival according to chemotherapy reagents in patients with native EGFR. D) Kaplan-Meier curve for progressionfree survival according to surgery in patients with native EGFR.

Figure S5. A) Kaplan-Meier curve for overall survival according to gender in patients with mutations in EGFR. B) Kaplan-Meier curve for overall survival according to surgery in patients with mutations in EGFR.

Figure S6. A) Kaplan-Meier curve for progression-free survival according to surgery in patients with mutations in EGFR. B) Kaplan-Meier curve for progression-free survival according to gender in patients with mutations in EGFR. C) Kaplan-Meier curve for progression-free survival according to tumor stage in patients with mutations in EGFR.

Figure S7. A) Kaplan-Meier curve for overall survival according to A-allele for MDM2 rs1690924 gene polymorphism in 141 NSCLC patients. B) Kaplan-Meier curve for overall survival according to T-allele of XRCC1 rs1799782 gene polymorphism in 141 NSCLC patients.

Figure S8. A) Kaplan-Meier curve for progression-free survival according to A-allele of MTR rs 1805087 gene polymorphism in 141 NSCLC patients. B) Kaplan-Meier curve for progressionfree survival according to G-allele of SLC19A1 rs1051266 gene polymorphism in patients 
treated with pemetrexed. C) Kaplan-Meier curve for progression-free survival according to Gallele of SLC19A1 rs1051266 gene polymorphism in 141 NSCLC patients.

Figure S9. A) Kaplan-Meier curve for overall survival according to G-allele of SLC19A1 rs1051266 gene polymorphism in patients with native EGFR. B) Kaplan-Meier curve for overall survival according to A-allele of MDM2 rs1690924 gene polymorphism in patients with native EGFR.

Figure S10. A) Kaplan-Meier curve for overall survival according to T-allele of ERCC1 rs3212986 gene polymorphism in patients with mutations in EGFR. B) Kaplan-Meier curve for overall survival according to G-allele of MTR rs1805087 gene polymorphism in patients with mutations in EGFR. C) Kaplan-Meier curve for overall survival according to G-allele of SLC19A1 rs 1051266 gene polymorphism in patients with mutations in EGFR.

Figure S11. A) Kaplan-Meier curve for progression-free survival according to A-allele of MTHFR rs1801131 gene polymorphism in patients with native EGFR. B) Kaplan-Meier curve for progression-free survival according to A-allele MTR rs1805087 gene polymorphism in patients with native EGFR.

Figure S12. A) Kaplan-Meier curve for progression-free survival according to T-allele of ERCC1 rs3212986 gene polymorphism in patients with mutations in EGFR. B) Kaplan-Meier curve for progression-free survival according to G-allele of ERCC2 rs13181 gene polymorphism in patients with mutations in EGFR. C) Kaplan-Meier curve for progression-free survival according to G-allele of MTR rs1805087 gene polymorphism in patients with mutations in EGFR. 